\title{
Feeding ecology of the mangrove crab Neosarmatium smithi (Crustacea: Decapoda: Sesarmidae)
}

\author{
R. L. Giddins ${ }^{1}$, J. S. $\operatorname{Lucas}^{1 *}$, M. J. Neilson ${ }^{2,3}$ \& G. N. Richards ${ }^{2,4}$ \\ ' Department of Zoology, James Cook University of North Queensland, Townsville, Queensland 4811, Australia \\ ${ }^{2}$ Department of Chemistry, James Cook University of North Queensland, Townsville, Queensland 4811, Australia \\ ${ }^{3}$ Department of Biochemistry, La Trobe University, Bundoora, Victoria 3083, Australia \\ ${ }^{4}$ Wood Chemistry Laboratory, University of Montana, Missoula, Montana 59812, USA
}

\begin{abstract}
Consumption experiments showed that the mangrove crab Neosarmatium smithi $\mathrm{H}$. Milne-Edwards preferred litter of the mangrove Ceriops tagal decayed for some weeks. Determination of assimilation efficiencies, using a $72 \%$ sulfuric acid insoluble residue as indigestible marker, revealed that $N$. smithi assimilated little of the components of a $2 \mathrm{wk}$ old Litter diet, but that assimilation efficiencies (carbon, nitrogen, caloric content, organic matter) ranged from 30 to $60 \%$ when fed 4,6 or 8 wk old litter. These values must be treated with caution because the validity of using a $72 \%$ sulfuric acid insoluble residue as an inert marker in determining assimilations in mangrove studies, as used here, is questioned. Due to the extremely high carbon-nitrogen ratios of the litter, these diets fall well below accepted nutritional standards. An additional source of nitrogen in the diet was determined by gut content analysis to be small crustaceans. $N$. smithi is not a direct link in the ecosystem food chain. Carrying the leaf litter into their burrows - where the leaves decay, are subsequently consumed, and faeces are produced - the crabs substantially reduce export of leaf litter by tidal transport and regenerate nutrients for other small invertebrates and the mangroves themselves
\end{abstract}

\section{INTRODUCTION}

Detrital material formed from mangrove leaf litter is considered to be the basis of food webs within mangrove ecosystems (Mann 1975, Odum \& Heald 1975). However, although certain macro-invertebrates have the ability to digest detrital matter directly (Adams \& Angelovic 1970, Yingst 1976, Foulds \& Mann 1978, Wainwright \& Mann 1982, Klumpp \& Nichols 1983), none of these organisms inhabits mangrove ecosystems. Several studies (Malley 1975, 1978, Beever et al. 1979, Wilson 1981, Mattson 1982) have shown significant consumption of mangrove leaf material by sesarmid crabs, but none assessed the ability of the organisms in question to actually assimilate the plant material.

Neosarmatium smithi, a large (50 mm carapace width) sesarminid crab, is the dominant crustacean in the Ceriops tagal australis zone of mangroves in the Townsville region (Australia). This zone is $3.1 \mathrm{~m}$ above chart datum, and is infrequently immersed. The crab

\footnotetext{
- Addressee for correspondence
}

emerges from its burrow at night to remove litter from the surface of the mud (Alexander pers. comm.). This study set out to determine at what stage of decomposition C. tagal leaves are consumed and which components of the leaf material are assimilated.

\section{MATERIALS AND METHODS}

Collection of leaf material. There were 3 collection sites in the region of Townsville, North Queensland, Australia (ca $19^{\circ} \mathrm{S}, 147^{\circ} \mathrm{E}$ ). Neosarmatium smithi $\mathrm{H}$. Milne-Edwards specimens and senescent Ceriops tagal leaves (defined as yellow and easily removed from trees) were collected at Cape Ferguson. Fresh leaves (mature, green) were collected from Ross River. Decayed leaves (black and fragmenting) were collected from Three Mile Creek. To produce detritus of known age, large collections of senescent leaves were made every $2 \mathrm{wk}$ for a period of $8 \mathrm{wk}$. The collections were divided into $40 \mathrm{~g}$ subsamples and placed into $150 \mathrm{~mm}$ square nylon mesh bags ( $2 \mathrm{~mm}$ mesh). Groups of 3 bags were tied to mangrove trees in Ross River at 
the mud surface. All bags experienced the same conditions and were able to float at high tide. The bags were recovered at the end of the tenth week to give a decomposition series designated SO 10 weeks decomposition), S2 ..., S10 leaves.

Representative sub-samples were removed, dry weighed $\left(60^{\circ} \mathrm{C}\right.$ for $\left.72 \mathrm{~h}\right)$ and ball-milled. These subsamples were either chemically analysed immediately or stored at $-20^{\circ} \mathrm{C}$ until required. The remainder of each leaf sample was either kept at $5{ }^{\circ} \mathrm{C}$ if consumption experiments were to be carried out within $3 \mathrm{~d}$, or kept frozen until use.

Feeding experiments. Consumption experiments were carried out at $25^{\circ} \mathrm{C} \pm 2 \mathrm{C}^{\circ}$ with a $12 \mathrm{~h}$ light $/ 12 \mathrm{~h}$ dark photoperiod. The crabs were kept individually in ventilated plastic containers with ca $25 \mathrm{ml}$ of seawater in the base to prevent desiccation. In an initial experiment, crabs were given mixtures of known weights of leaves of fresh, senescent, and decayed condition. After $24 \mathrm{~h}$ the leaf material was removed, sorted into the 3 different types, and weighed after surface drying (by blotting). Four controls, without crabs, were also run, and the specific consumption rate (SCR) data ( $g$ wwt of leaf $\mathrm{g}^{-1}$ crab $24 \mathrm{~h}^{-1}$ ) were corrected accordingly. Some leaf material was finely fragmented but not ingested and this could not be distinguished from faecal particles, and thus consumption is here defined as having been processed by the mouthparts. In a second experiment, crabs were fed each leaf type in the Ceriops tagal decay series separately. In this case, SCR was expressed in terms of leaf dry weight (dwt). One half of a leaf was wet weighed and fed to the crabs, and the other half dry weighed. After $24 \mathrm{~h}$ the remains were removed, dried, and weighed to give SCR values. Again, controls without crabs were used. SCR was then expressed as relative consumption rate (RCR):

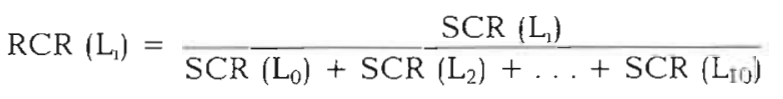

where $\mathrm{L}_{0}=0$ wk litter, etc. This gives the SCR of 1 $c r a b$, on a particular diet, relative to the total of its SCRs for all diets. RCR is dimensionless, and as such crab weight has no effect on it.

Bacterial counts. Bacterial numbers on litter were determined as in Hobbie et al. (1977), except that homogenization was used in the place of ultrasonication. Ellery \& Schleyer (1984) consider the latter method more effective, but they were studying sediments. Bacteria within the leaf tissue may not have been revealed with ultrasonication. The dilution water was kept bacteria-free by the addition of 'Tween 80 ' at a concentration of $50 \mathrm{mg} \mathrm{l}^{-1}$. Two samples of each of the 5 litter types were taken. From each of these, 2 filter preparations were made, and 10 microscope frames were counted for each filter.

Fractionation of samples into water-soluble and insoluble components. Microbial and mud contamination of decay series leaves made it necessary to modify the fractionation procedure described by Neilson et al. (1986). Leaf samples (S2 to S10), with petioles removed, were cut into ca $1 \mathrm{~cm}^{2}$ pieces, extracted with hot acetone $\left(10 \mathrm{ml}\right.$ acetone $\mathrm{g}^{-1}$ wwt sample) for $15 \mathrm{~min}$ and gently vacuum filtered through Terylene cloth, which allowed mud and microbial matter to pass through. Extraction was repeated, the mixture cooled, homogenized and filtered. The cloth was folded about the leaf material and then sonicated in cold acetone until most of the mud was removed. Although some mud 'coating' was visible on the larger meal fragments of $\mathrm{S} 8$ and $\mathrm{S} 10$, it was assumed that its contribution to the total dry weight would be minimal. Corresponding faecal samples (F2 to F10) were treated similarly but without the homogenization and sonication steps.

The acetone-insoluble residues were then extracted (24 h) under nitrogen in the dark, with ethylenediaminetetra-acetic acid (EDTA:0.1M, pH6, $25^{\circ} \mathrm{C}$; $40 \mathrm{ml}$ EDTA $\mathrm{g}^{-1} \mathrm{dwt}$ sample). The slurry was cooled, centrifuged $\left(4^{\circ} \mathrm{C}, 10000 \times{ }^{\prime} \mathrm{g}\right.$ ') for $30 \mathrm{~min}$, and the supernatant aspirated off and held at $4{ }^{\circ} \mathrm{C}$. The extraction was repeated and the combined supernatants were exhaustively dialysed in the dark $\left(4^{\circ} \mathrm{C}, 48 \mathrm{~h}\right)$ against distilled water in pre-washed tubing, freezedried and weighed to yield the EDTA-soluble component.

The EDTA-insoluble fractions were washed thoroughly with water by centrifugation, acetone dried at the pump, vacuum dried ( $1 \mathrm{~mm} \mathrm{Hg},<40^{\circ} \mathrm{C}, \mathrm{P}_{2} \mathrm{O}_{5}, 12 \mathrm{~h}$ ) and weighed.

Analyses. Caloric value of samples was determined using a Gallenkamp Ballistic Bomb Calorimeter. Ash Free Dry Weight (AFDW) was determined by ashing dried samples at $500^{\circ} \mathrm{C}$ for $16 \mathrm{~h}$ (Rice \& Tenore 1981). Carbon and nitrogen analyses were performed in a 'Leco' CHN600 Elemental Analyser. Proteinaceous nitrogen was defined as that nitrogen lost after boiling in $5 \%$ potassium hydroxide (Odum et al. 1979).

Carbohydrate contents were determined by the phenol-sulfuric method (Dubois et al. 1956). For EDTA-soluble fractions, the method was applied as described in Neilson et al. (1986). EDTA-insoluble fractions were subjected to total acid hydrolysis based on modified Saeman conditions (Saeman et al. 1954) prior to assaying. Samples ( 15 to $25 \mathrm{mg}$ ) were weighed into a centrifuge tube $(10 \mathrm{ml})$, triturated with $72 \%$ sulfuric acid $(100 \mu \mathrm{l})$ at $25^{\circ} \mathrm{C}$ and kept in a desiccator with occasional stirring for $1 \mathrm{~h}$. Water was added $(2.8 \mathrm{ml})$ and the tube and contents tared prior to secondary hydrolysis under reflux for $3 \mathrm{~h}$ at $100^{\circ} \mathrm{C}$. The mix- 
ture was cooled, weight adjusted with water (if necessary), centrifuged $(1000 \times$ ' $\mathrm{g}$ ', $10 \mathrm{~min})$ and aliquots taken for phenol-sulfuric assay. The insoluble residues produced on hydrolysis were washed free of acid (check by $\mathrm{pH}$ paper) with water, vacuum dried and weighed. These 'crude lignin' samples were ashed $\left(600^{\circ} \mathrm{C}, 4 \mathrm{~h}\right)$, weight adjusted, reported as acid-insoluble residue, and used to calculate assimilation efficiency values (see below).

Newly-recognized flavologlycan (FG) (Neilson et al. 1986) was present in the EDTA-soluble fraction isolated as described above. Total flavolan or condensed tannin content in the fraction was estimated colorimetrically by the vanillin- $\mathrm{HCl}$ method detailed in Broadhurst \& Jones (1978) with catechin as a reference. Since the reactivity of the vanillin reagent with catechin is much greater than with flavolans (Goldstein \& Swain 1963), these values indicate the relative amounts of total flavolan content.

Model leaching experiment. Intact senescent leaves $(49 \mathrm{~g}, 21 \mathrm{~g} \mathrm{dwt})$ were placed in a $1 \mathrm{l}$ flask and immersed in sterilized, artificial sea-water $(800 \mathrm{ml})$ (Reichelt \& Baumann 1973). Sodium azide $(0.02 \%)$ was added to prevent any microbial activity. The flask was capped with aluminium foil and kept at $25^{\circ} \mathrm{C}$ in the dark. After 2 and $4 \mathrm{wk}$, filtered (Millipore, $0.45 \mu \mathrm{m}$ ) aliquots of the 'mother liquor' were analysed for flavolan and total carbohydrate.

Assimilation efficiency (AE). AE was estimated by comparing the proportion of a dietary component in the food to that in the faeces relative to an indigestible marker substance (Klumpp \& Nichols 1983), in this case, the insoluble residue after acid hydrolysis (see above). Klumpp \& Nichols used a similar 'lignin' material as the marker (see below). Preliminary experiments showed that starving crabs may take more than a week to evacuate their guts, thus precluding the use of a simpler quantitative method for determining AE. Crabs were fed a particular diet for $2 d$, the chambers were cleaned, and the crabs returned together with litter of the same type as before. Faecal matter was collected after a further $24 \mathrm{~h}$ and frozen for later analysis.

Table 1. Neosarmatium smithi. Consumption rates when offered a choice of fresh, senescent and decayed Ceriops tagal leaves

\begin{tabular}{lc} 
Leaf type & $\begin{array}{c}\text { Mean specific consumption rate } \\
\text { (g wwt leaf } \mathrm{g}^{-1} \mathrm{crab} \mathrm{24}^{-1} \text { ) }\end{array}$ \\
\hline Fresh & $0.004(0.006)^{\circ}$ \\
Senescent & $0.011(0.014)$ \\
Decayed & $0.062(0.055)$ \\
${ }^{*} \pm 1$ standard deviation &
\end{tabular}

Gut content analysis. Five specimens were caught in the field for gut analysis. They were killed by destroying the major thoracic ganglion, preserved in $30 \%$ seawater formalin and dissected within $24 \mathrm{~h}$. At a magnification of $40 \times, 10$ frames were assessed from each sample. The proportion of the total volume of the gut made up by each food type was thus estimated.

\section{RESULTS}

\section{Gut content analysis}

Gut analysis of 5 Neosarmatium smithi showed that plant material was $90 \pm 7 \%$ (mean $\pm 1 \mathrm{SD}$ ) of the total volume of the gut, animal material was $8 \pm 2 \%$, and the remainder was unidentifiable. The vast majority of the animal material was crustacean in origin.

\section{Mechanical alteration of leaf litter by $N$. smithi}

Fig. 1 illustrates several SEM views of the teeth of the gastric mill of Neosarmatium smithi. These show a series of heavily dentate ridges that interlock when the laterial teeth pass over the dorsal tooth (Fig. 1a, b, c). Also, a number of curved 'spines' (Fig. 1d) that meet together over the dorsal tooth are visible.

\section{Consumption rates}

When offered a choice of fresh, senescent, and decayed Ceriops tagal leaves (Table 1), Neosarmatium smithi exhibited a distinct preference for decayed material (1-way ANOVA, p $<0.0001$ ).

A partial correlation of SCR with litter type, controlling for the effect of crab weight, revealed that the effect of leaf age on SCR was significant above any effect of crab weight ( $\mathrm{r}=0.41, \mathrm{p}<0.0001)$. The consumption rate was expressed as RCR to determine an accurate relationship with decomposition stage. This tranformation was performed on all crabs fed on all types of litter. A plot of RCR against litter type (Fig. 2) shows that a maximum $R C R$ is reached for the $S 6$ litter (mean RCR at S6 litter $=21.1 \%$ ).

\section{Assimilation efficiencies for Ceriops tagal decay series}

Tables 2, 3 and 4 list the quantities of the various components of food and faeces, and Table 5 shows AE values for these components for all litter types except So leaves. 
a

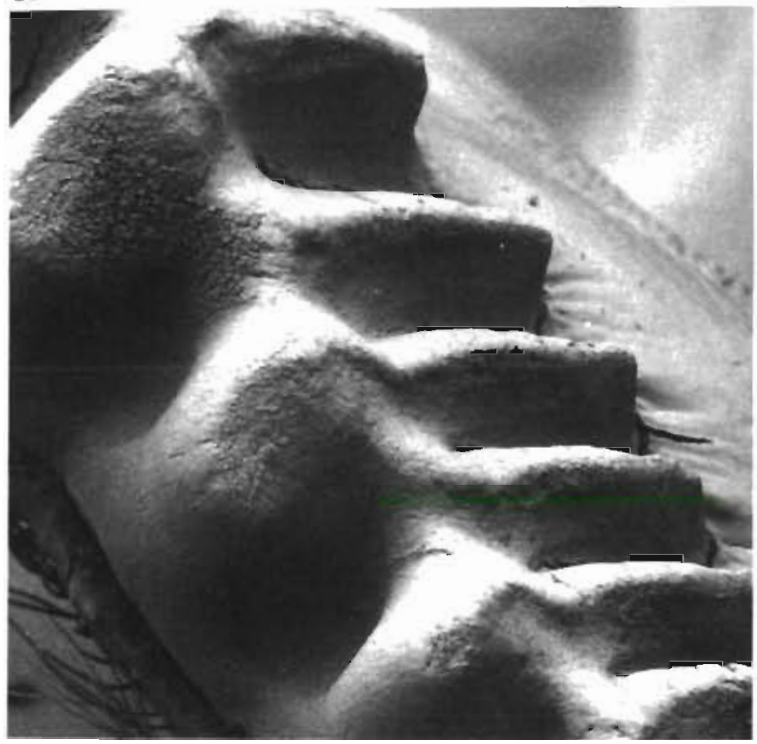

C

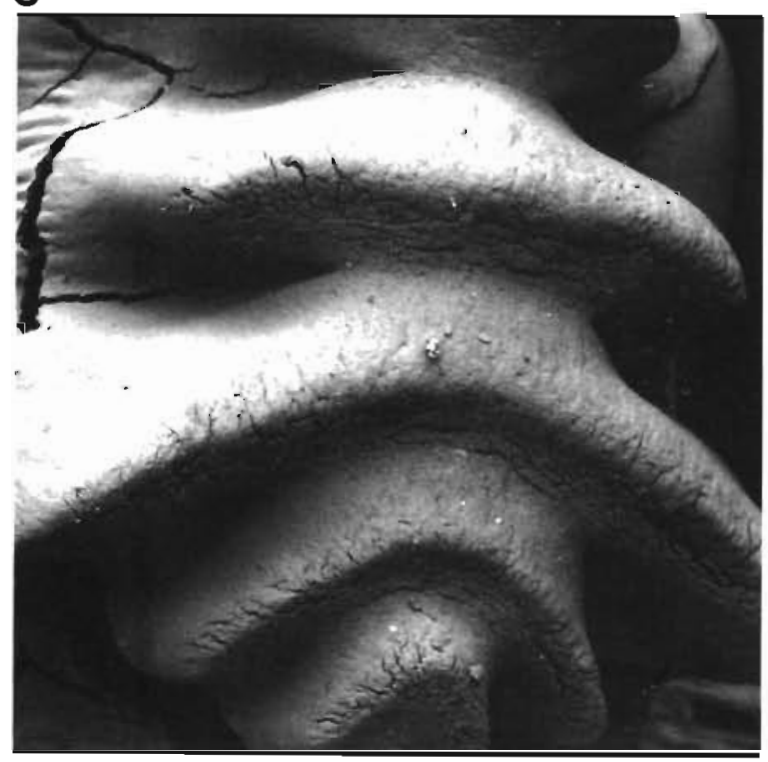

b

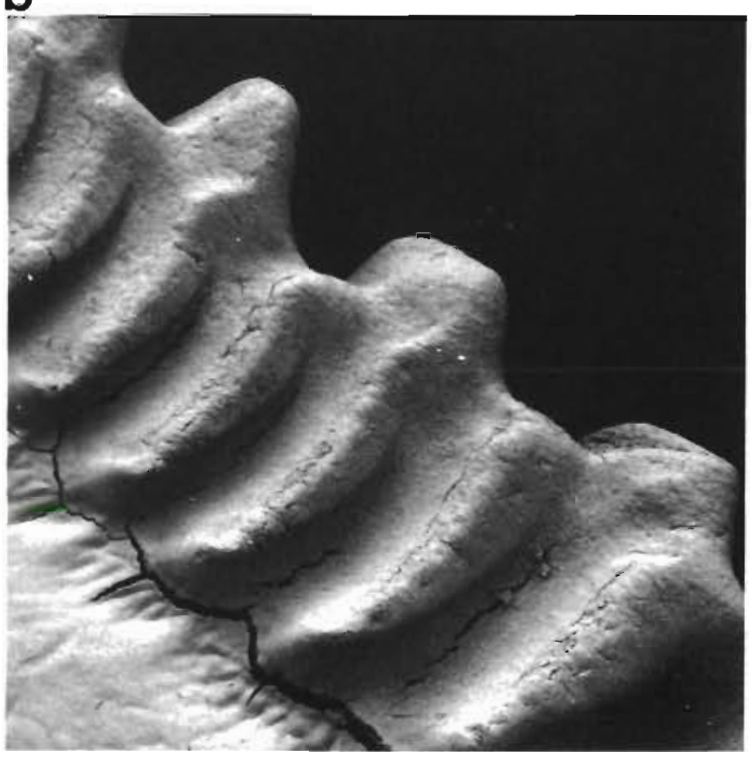

d

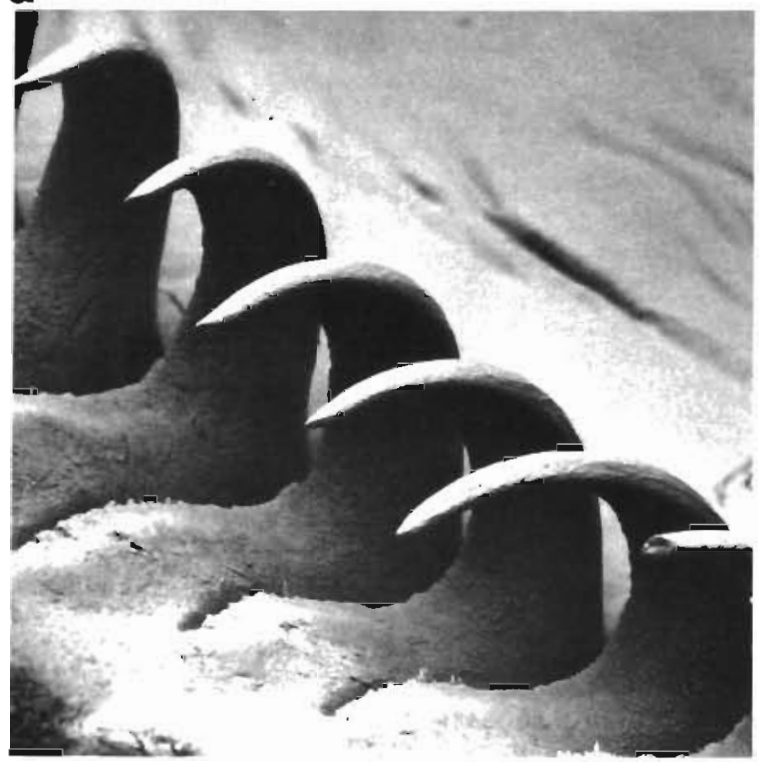

Fig. 1 Neosarmatum smithi. Electron micrographs of dorsal and lateral teeth of the gastric mill. (a) and (b) A lateral tooth showing other large ridges which interlock with those on the dorsal tooth. (c) Dorsal tooth seen ventrally, showing large ridges used in crushing plant fibres.(d) Large spines on a lateral tooth possibly used for keeping food in place. All scales $100 \mu \mathrm{m}$

When both flavolan and soluble carbohydrate components were present (S2 and S4 litters) they were totally assimilated. The insoluble carbohydrates were assimilated from the S2 and S4 litters (56 and 35\% respectively), but negative AEs were recorded for the S6, S8 and S10 litters $(-44,-115$, and $-63 \%$ respectively). The AEs for the nitrogen, carbon, organic matter (AFDW), and energy components were either low or slightly negative for the S2 litter $(-2,1,-1$, and $-1 \%$ respectively). For the S4, S6, and S8 litters, AE values ranged between 24 and $59 \%$. In the S10 litter all of these components were assimilated only in small amounts, AE values ranging from 4 to $10 \%$. AE for bacteria in the S10 litter was only $9 \%$

The possibility that some of the carbohydrate content shown in Tables 2 and 3 was derived from bacterial polysaccharides is eliminated since these would have been removed during the isolation procedure 


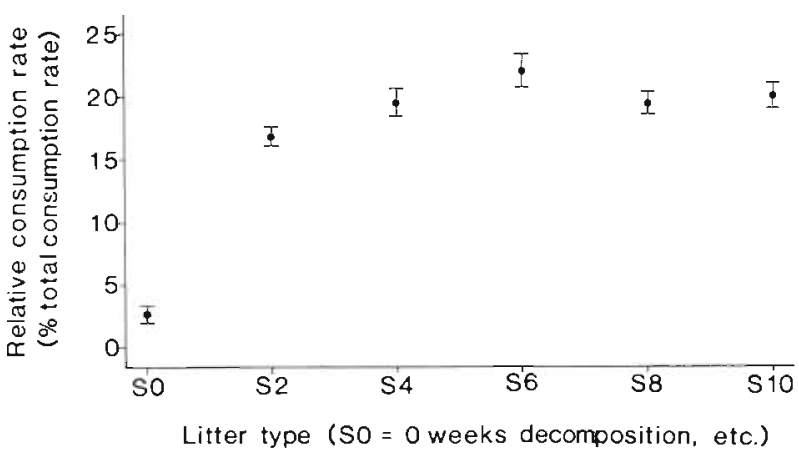

Fig. 2. Neosarmatium smithi. Relative consumption rate when fed on various litter types. Plotted as mean \pm standard deviation

\section{DISCUSSION}

\section{Consumption of leaf litter by Neosarmatium smithi}

Gut content analyses indicate that leaf litter is the major component in the diet of Neosarmatium smithi. Electron micrographs of the gastric mill detail graphically how well $N$. smithi is adapted to feeding on this material. A similar gastric mill is found in the mangrove tree crab Aratus pisonii which is also known to consume mangrove leaves (Warner 1977). As contrasting gastric mill ossicles are found in crabs that have alternative feeding habits (Warner 1977) this mill would seem to be specifically adapted to deal with vascular plant material.

Table 2. Compositional analysis of Ceriops tagal litter types S0 to S10

\begin{tabular}{|c|c|c|c|c|c|c|c|}
\hline \multirow[t]{2}{*}{ Sample } & \multicolumn{7}{|c|}{ Component ( $\%$ total dry weight) } \\
\hline & Nitrogen ${ }^{1}$ & Carbon $^{1}$ & $\mathrm{AFDW}^{1}$ & $\begin{array}{l}\text { EDTA-soluble }{ }^{2} \\
\text { carbohydrate }\end{array}$ & Flavolan ${ }^{3}$ & $\begin{array}{l}\text { EDTA-insoluble }{ }^{2} \\
\text { carbohydrate }\end{array}$ & $\begin{array}{l}\text { Acid-insoluble }^{4} \\
\text { residue }\end{array}$ \\
\hline $\mathrm{SO}^{5}$ & $0.2(0.01)$ & $36.7(0.4)$ & $77.0(0.3)$ & 1.8 & 4.9 & 25.1 & 15.0 \\
\hline $\mathrm{S} 2$ & $0.4(0.01)$ & $38.4(0.1)$ & $71.2(2.3)$ & 1.4 & 3.0 & 26.6 & 30.7 \\
\hline S4 & $0.4(0.02)$ & $39.7(0.2)$ & $73.4(0.5)$ & 1.3 & 2.0 & 16.6 & 27.6 \\
\hline S6 & $0.4(0.00)$ & $35.2(0.9)$ & $65.2(2.0)$ & 0.7 & 0.2 & 7.7 & 26.4 \\
\hline S8 & $0.4(0.01)$ & $38.2(0.1)$ & $69.4(1.1)$ & 0.5 & 0.1 & 3.8 & 17.9 \\
\hline $\mathrm{S} 10$ & $0.6(0.05)$ & $39.7(0.1)$ & $70.1(2.5)$ & 0.0 & 0.1 & 11.5 & 37.1 \\
\hline \multicolumn{8}{|c|}{${ }^{\prime} \pm 1$ standard deviation } \\
\hline \multicolumn{8}{|c|}{${ }^{2}$ By phenol-sulfuric acid method using D-glucose as standard } \\
\hline \multicolumn{8}{|c|}{${ }^{3}$ By vanillin-hydrochloric acid method (catechin equivalents) } \\
\hline \multicolumn{8}{|c|}{${ }^{4}$ Residue remaining after total acid hydrolysis } \\
\hline${ }^{5} \mathrm{SO}=\mathrm{le}$ & es aged for & , etc... & & & & & \\
\hline
\end{tabular}

Table 3. Neosarmatium smithi. Compositional analysis of faecal matter produced when fed on litter types S2 to S10

\begin{tabular}{|c|c|c|c|c|c|c|c|}
\hline \multirow[t]{2}{*}{ Sample } & \multicolumn{7}{|c|}{ Component ( $\%$ total dry weight) } \\
\hline & Nitrogen $^{1}$ & Carbon $^{1}$ & AFDW & $\begin{array}{l}\text { EDTA-soluble } \\
\text { carbohydrate }\end{array}$ & Flavolan ${ }^{3}$ & $\begin{array}{l}\text { EDTA-insoluble } \\
\text { carbohydrate }\end{array}$ & $\begin{array}{l}\text { Acid-insoluble } \\
\text { residue }\end{array}$ \\
\hline $\mathrm{F}^{5}{ }^{5}$ & $0.4(0.04)$ & $37.4(0.0)$ & 70.4 & Neg. ${ }^{6}$ & Neg. & 11.5 & 30.2 \\
\hline F4 & $0.3(0.03)$ & $38.2(0.0)$ & 70.1 & Neg. & Neg. & 14.3 & 36.7 \\
\hline F6 & $0.4(0.04)$ & $36.0(0.0)$ & 60.4 & Neg. & Neg. & 18.2 & 43.3 \\
\hline F8 & $0.4(0.05)$ & $38.3(0.0)$ & 64.5 & Neg. & Neg. & 18.6 & 40.8 \\
\hline F10 & $0.6(0.04)$ & $39.2(0.0)$ & 66.9 & Neg. & Neg. & 18.7 & 39.9 \\
\hline \multicolumn{8}{|c|}{$1 \pm 1$ standard deviation } \\
\hline \multicolumn{8}{|c|}{${ }^{2}$ By phenol-sulfuric acid method using D-glucose as a standard } \\
\hline \multicolumn{8}{|c|}{${ }^{3}$ By vanillin-hydrochloric acid method (catechin equivalents) } \\
\hline \multicolumn{8}{|c|}{${ }^{4}$ Residue remaining after total acid hydrolysis } \\
\hline \multicolumn{8}{|c|}{${ }^{5} \mathrm{~F} 2$ = faeces from crabs fed on $\mathrm{S} 2$ litter, etc... } \\
\hline${ }^{6}$ Negligik & & & & & & & \\
\hline
\end{tabular}


Table 4. Neosarmatium smithi. Caloric values and bacterial counts for food used and corresponding faecal matter produced when fed on different litter types

\begin{tabular}{|c|c|c|c|c|}
\hline \multirow[t]{2}{*}{$\begin{array}{l}\text { Litter } \\
\text { type }\end{array}$} & \multicolumn{2}{|c|}{$\begin{array}{c}\text { Bacterial counts } \\
\left(10^{7} \mathrm{~g}^{-1} \mathrm{dwt}\right)\end{array}$} & \multicolumn{2}{|c|}{$\begin{array}{c}\text { Caloric value } \\
\left(\mathrm{kJ} \mathrm{g}^{-1} \text { AFDW }\right)\end{array}$} \\
\hline & Food & Faeces & Food & Faeces \\
\hline So & -1 & - & $26.6(0.9)^{2}$ & - \\
\hline $\mathrm{S} 2$ & - & - & $29.8(4.5)$ & 21.1 \\
\hline S4 & - & - & $27.4(1.0)$ & 20.3 \\
\hline S6 & - & - & $32.4(2.9)$ & 21.2 \\
\hline S8 & - & - & $30.0(2.1)$ & 20.7 \\
\hline $\mathrm{S} 10$ & $38.6(6.3)$ & $35.5(6.8)$ & $30.1(5.1)$ & 21.2 \\
\hline \multicolumn{5}{|c|}{${ }^{1}$ Not determined } \\
\hline
\end{tabular}

Vallis \& Jones 1973, Wong 1973, Daiber 1975). It is quite conceivable that in this case the FG concentration in the leaves is rapidly reduced by leaching and then the micro-organisms grow on the leaves and/or $N$. smithi consumes the leaves. This postulate is consistent with the findings of Ford (1978). In a comparative study on the influence of chemical composition on the digestibility of several pasture legumes, he found that Desmodium intortum had a high polyphenol concentration $(20 \%)$ and an associated low relative digestibility. He showed that $D$. intortum digestibility was significantly increased when the polyphenols were extracted prior to incubation. The interaction between FG and protein needs to be investigated using specific enzyme preparations and pertinent microbial populations.

Table 5. Neosarmatium smithi. Assimilation efficiencies of the various components of litter types S2 to S10

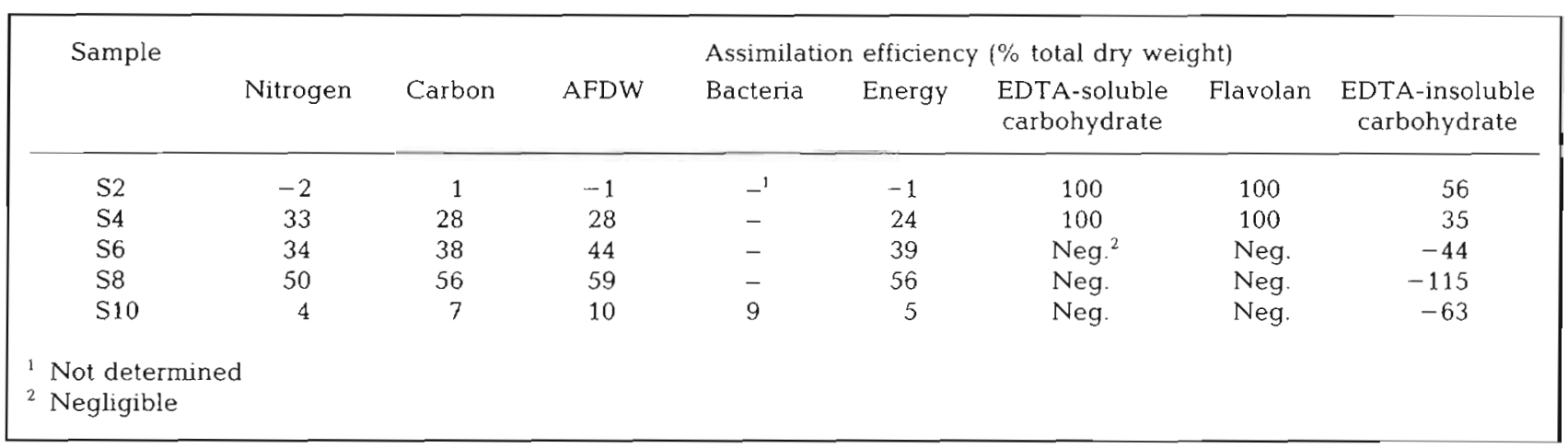

\section{Consumption rates}

The preference shown for aged litter by Neosarmatium smithi in both experiments suggests that leaves taken into their burrows are stored before consumption. This was seen by Kneipp \& Alexander (unpubl.) when they kept crabs in artificial burrows that permitted observation of their behaviour: the crabs placed So leaves on the walls of the burrow instead of eating them. The immediate cause for this behaviour is probably the more acceptable 'taste' of aged leaves. Rapid leaching of flavologlycan from SO leaves occurs, as shown in a model experiment. After 2 and $4 \mathrm{wk}, 26$ and $58 \%$ of the total flavolan (vanillin/ $\mathrm{HCl}$ ) had leached from the leaves. Concurrently, 16 and $27 \%$ of the available soluble carbohydrates (including low molecular weight constituents) were solubilized. Most likely, the leached FG has astringent properties because flavolans (condensed tannins) are astringent (Goldstein \& Swain 1963, Bate-Smith 1973). Consequently, plant tissues are rendered unpalatable (Cope \& Burns 1971, Burns et al. 1972) or the flavolans present will immobilize enzymes, thus impeding microbial degradation of the tissues (Bate-Smith 1973,
In addition to this, an advantage of delayed consumption is that the carbon/nitrogen ratio is reduced. The $\mathrm{C} / \mathrm{N}$ ratio of $\mathrm{S} 0$ leaves (183:1) is well above the maximum 17:1 value prescribed by Russell-Hunter (1970) as being necessary for a nutritional food. Also, Tenore (1977, 1981, 1983a, b) has determined that nitrogen is an important factor governing the availability of detritus to a consumer. As the relative nitrogen content of detritus increases with decomposition (de la Cruz \& Gabriel 1974, Gosselink \& Kirby 1974), by allowing decomposition the crab will reduce the high $\mathrm{C} / \mathrm{N}$ ratio problem and increase nutrient availability

The effect of crab weight on SCR was to be expected as smaller organisms usually have a higher specific metabolic rate (Gordon 1977). The lesser effect with S0 leaves is probably due to the generally lower consumption rates suppressing this effect.

The RCR reaches $91 \%$ of the assymptote in the S6 litter and increases extremely slowly after this point, indicating that factors affecting the consumption rate are negligible after $6 \mathrm{wk}$ decomposition. As near maximum consumption rate is reached at this point, the litter is probably consumed at or before this stage. However, with the $\mathrm{S} 6$ type leaves having a $\mathrm{C} / \mathrm{N}$ ratio of 
100:1, they are still far above the 17:1 maximum suggested by Russell-Hunter (1970), and hence there must be another source of nitrogen. Gut content analysis shows that the detritus diet is supplemented by predation on small invertebrates.

\section{Assimilation efficiencies}

The markers used here and in the study by Klumpp \& Nichols (1983) are essentially the same; they defined 'lignin' as the residue from hydrolysis in $72 \%$ sulfuric acid, after the initial removal of protein (van Soest 1963). In this study there was no protein removal. However, as the protein content of these litters is never greater than $3.1 \%$, and is mostly bacterial, the result should not be significantly affected.

The existence of a low AE for bacteria, some negative AEs for the S6, S8, and S10 litters, and the inconsistency of results when comparing the $\$ 10$ litter to the S4, S6, and S8 litters suggests that the use of an acidinsoluble residue as a marker may not be accurate. The method employed here assumed that the marker used was inert in acid and was not assimilated at all by Neosarmatium smithi. Since up to $50 \%$ of the dry weight of the newly senescent leaves of Ceriops tagal consists of polyphenols (M. Neilson unpubl.), it would be reasonable to expect that a portion of these polyphenols is acid-soluble, and this would lessen the significance of using 'lignin' as an inert internal marker in mangrove studies, since it is assumed that such a marker is inert in the gut and in acid. It is also probable that errors will arise as the polyphenols which generate the acid-insoluble 'lignin' vary during decomposition, leaching and passage through the digestive system. This factor may be especially important for the polyphenols which are bonded to polysaccharides as flavologlycans. Some aromatic products from acid hydrolysis of FG are acid-soluble and some are acid-insoluble. The ratio may vary due to the chemical nature of the flavolan moiety. More accurate efficiencies would have been determined by feeding the crabs, which had cleared their guts previously, with a known weight of litter, and collecting a known weight of corresponding faeces. However, as reported in the 'Materials and Methods', this was not possible.

Previous studies have shown that detritivores can assimilate a significant proportion of the non-living plant fraction of detritus (e.g. Adams \& Angelovic 1970, Foulds \& Mann 1978, Wainwright \& Mann 1982). Klumpp \& Nichols' (1983) study - which documented that the portunid crab Nectocarcinus integrifons is able to assimilate up to $60 \%$ of the components of the seagrass Posidonia australis - is, however, now questioned due to possible inaccuracies of the method involved, as determined here. (In this publication cellulose and hemicellulose were incorrectly defined in the footnote of their Table III: cellulose and hemicellulose terms must be interchanged.)

The total assimilation of the flavolan fraction is not under question here as there were only negligible amounts left in the faeces. Since this fraction is soluble, the water in the experimental container was also analysed for flavolans, but it contained none. The $100 \%$ assimilated flavolan refers to the FG component only. Natural tannins consist of several different flavolans that can be separated according to their solubility in aqueous and non-aqueous solvents (Ribereau-Gayon 1972). With their high polyphenolic concentrations, this property may easily be confounded in original and aged mangrove leaves. A check for absolute methanolsoluble (Ribereau-Gayon 1972) flavonoid material in the EDTA-insoluble residues from S2, F2, S8, and F8 showed that $5.8 \%$ of the $\mathrm{S} 2$ residue dry weight (i.e. $3.9 \%$ of the total leaf dwt) consisted of this material, with $<1 \%$ being found in the remainder. Hence, EDTA (or water) extraction readily removed FG (flavolan bonded to polysaccharides) leaving low molecular weight flavolans soluble in absolute methanol. The flavolans would be original plant tissue components or, in the case of aged leaves, produced by various degradative processes. Detailed categorisation of the complex flavolans obviously present in these plant tissues was beyond the scope of this work. For the S2 diet, the amount of absolute methanol-soluble material in the EDTA-insoluble fraction was reduced by $85 \%$ after passage through the gut, suggesting apparent assimilation by Neosarmatium smithi. This indicates that $N$. smithi has a mechanism for eliminating some 'tannins'. It is possible that, although the flavolan fraction can be dealt with to some extent, it may still have a deleterious effect on assimilation. This could be by the flavolans inhibiting digestive enzymes. Thus there would still be lower assimilation efficiencies when flavolans were present before consumption.

\section{Ecological implications}

No implications can be inferred from AEs due to possible inaccuracies of the method employed. The removal of litter from the mud surface by Neosarmatium smithi is important in that this retains the nutrients present in the leaves within the mangrove ecosystem, allowing circulation back to the mangroves themselves. Faecal material of $N$. smithi is of considerable ecological significance. Faecal pellets have long been known to be important as sites of microbial activity and as food sources for many detritivores (e.g. Hargrave 1970). The considerable proportion of car- 
bohydrates left in faecal matter by $N$. smithi (ca $18 \%$ ) will probably be useful to other detritivores as food. The removal of the flavolan fraction will greatly increase the availability of the detritus to other detritivores. These 'other' detritivores will mainly have to exist in the burrows of $N$. smithi. The crabs spend so little time out of their burrows that the great bulk of their faecal material will be deposited within the burrow. Habitation in the burrows will be restricted to small crustaceans and polychaetes.

Acknowledgements. This study was supported by grants from the Australian Marine Science and Technologies Grants Scheme and James Cook University of North Queensland. We thank Dr. Alistar Robertson of the Australian Institute of Marine Science for critically reading this paper, and also the various people who assisted in field and laboratory work.

\section{LITERATURE CITED}

Adams, S. M., Angelovic, J. W. (1970). Assimilation of detritus and its associated bacteria by three species of estuarine animals. Chesapeake Sci. 11: 249-254

Bate-Smith, E. C. (1973). Haemanalysis of tannins: the concept of relative astringency. Phytochemistry 12: 907-912

Beever, J. W., Simberloff, D., King, L. L. (1979). Herbivory and predation by the mangrove tree crab Aratus pisonii. Oecologia (Berl.) 43: 317-328

Broadhurst, R. B., Jones, W. T. (1978). Analysis of condensed tannins using acidified vanillin. J. Sci. Fd Agric. 29: 788-794

Burns, J. C., Mochrie, R. D., Cope, W. A. (1972). Responses of dairy heifers to crownvetch, sericea Iespedeza and alfalfa forages. Agron. J. 64: 193-195

Cope, W. A., Burns, J. C. (1971). Relationship between tannin levels and nutritive value of sericea. Crop Sci. 11: 231-233

Cruz, A. A., de la, Gabriel, B. C. (1974). Caloric, elemental, and nutritive changes in decomposing Juncus roemerianus leaves. Ecology 55: 882-886

Daiber, K. H. (1975). Enzyme inhibition by polyphenols of sorghum grain and malt. J. Sci. Fd Agric. 26: 1399-1411

Dubois, M., Gilles, K. A., Hamilton, J. K., Rebers, P. A., Smith, F. (1956). Colorimetric method for determination of sugars and related substances. Analyt. Chem. 28: 350-356

Ellery, W. N., Schleyer, M. H. (1984). Comparison of homogenization and ultrasonication as techniques in extracting attached sedimentary bacteria. Mar. Ecol. Prog. Ser. 15: 247-250

Foulds, J. B., Mann, K. H. (1978). Cellulose digestion in Mysis stenolepis and its ecological implications. Limnol. Oceanogr. 23: 760-766

Ford, C. W. (1978). In vitro digestibiluty and chemical composition of three tropical pasture legumes, Desmodium intortum c.v. Greenleaf, D. tortuosum, and Macroptilium atropurpureum c.v. Siratro. Aust. J, agric. Res. 29: 963-974

Goldstein, J. L., Swain, T. (1963). Changes in tannins in ripening fruits. Phytochemistry 2: 371-383

Gordon, M. S. (1977). Animal physiology, principles and adaptation. 3rd edn. MacMillan, New York

Gosselink, J. G., Kirby, C. J. (1974). Decomposition of salt marsh grass Spartina alterniflora Loisel. Limnol. Oceanogr. 19: 825-832

Hargrave, B. T. (1970). The effect of a deposit feeding amphipod on the metabolism of benthic microflora. Limnol. Oceanogr. 15: 21-30

Hobbie, J. E., Daley, R. J., Jasper, S. (1977). Use of nucleopore filters for counting bacteria by fluorescence microscopy. Appl. environ. Microbiol. 33: 1225-1228

Klumpp, D. W., Nichols, P. D. (1983). Utilisation of the seagrass Posidonia australis as food by the rock crab Nectocarcinus integrifons (Latreille) (Crustacea: Decapoda: Portunidae). Mar. Biol. Lett. 4: 331-339

Malley, D. F. (1975). Detritus production in a tropical mangrove swamp: role of sesarmid crabs. Abstracts of the 38th annual meeting of the American Society of Limnology and Oceanography, June 23-26, Halifax

Malley, D. F. (1978). Degradation of mangrove leaf litter by the tropical sesarmid crab Chiromanthes onychophorum. Mar. Biol. 49: 377-386

Mann, K. H. (1975). Decomposition of marine macrophytes. In: Anderson, J. M., Macfadyen, A. (ed.) The role of terrestrial and aquatic organisms in decomposition processes. Blackwell Scientific, London, p. 247-268

Mattson, R. A. (1982). Feeding ecology of the mangrove tree crab Aratus pisonii (Milne-Edwards): selection of older leaves for herbivory. Fl. Scient. 45 (Suppl.): 26 (Abstract)

Neilson, M. J., Painter, T. J., Richards, G. N. (1986). Flavologlycan: a novel glycoconjugate from leaves of mangrove (Rhizophora stylosa Griff). Carbohydr. Res. 147: 315-324

Odum, W. E., Heald, E. J. (1975). The detritus based food-web of an estuarine mangrove community. In: Cronin, L. E. (ed.) Estuarine research, Volume 1. Academic Press, New York, p. 265-286

Odum, W E., Kirk, P. W., Zieman, J. C. (1979). Non-protein nitrogen compounds associated with particles of vascular plant detritus. Oikos 32: 363-367

Reichelt, J. L., Baumann, P. (1973). Taxonomy of the marine, luminous bacteria. Arch. Mikrobiol. 94: 283-330

Ribereau-Gayon, P. (1972). The tannins. In: Heywood, V. H. (ed.) Plant phenolics. Hafner Publishing Company, New York, p. 169-197

Rice, D. L., Tenore, K. R. (1981). Dynamics of carbon and nitrogen during the decomposition of detritus derived from estuarine macrophytes. Estuar. coast. Shelf Sci. 13: $681-690$

Russell-Hunter, W. D. (1970). Aquatic productivity: an introduction to some basic aspects of biological oceanography and limnology. Collier/MacMillan, London

Saeman, J. F., Moore, W. E., Mitchell, R. L., Millett, M. A. (1954). Techniques for the determination of pulp constituents by quantitative paper chromatography. Tappi 37: 336-343

Soest, P. J., van (1963). Use of detergents in the analysis of fibrous feeds. II. A rapid method for the determination of fiber and lignin. J. Ass. off. agric. Chem. 46: 829-835

Tenore, K. R. (1977). Growth of Capitella capitata cultured on various levels of detritus derived from different sources. Limnol. Oceanogr. 22: 936-941

Tenore, K. R. (1981). Organic nitrogen and caloric content of detritus I. Utilisation by the deposit feeding polychaete Capitella capitata. Estuar. coast. Shelf Sci. 12: 39-47

Tenore, K. R. (1983a). What controls the availability to animals of detritus derived from vascular plants: organic nitrogen enrichment or caloric availability? Mar. Ecol. Prog. Ser. 10: 307-309

Tenore, K. R. (1983b). Organic nitrogen and caloric content of detritus III. Effect on growth of a deposit feeding polychaete, Capitella capitata. Estuar. coast. Shelf Sci. 17: 733-742

Vallis, I., Jones, R. J. (1973). Net mineralization of nitrogen in 
leaves and leaf litter of Desmodium intortum and Phaseolus atropurpureus mixed with soil. Soil. Biol. Biochem. 5: 391-398

Wainwright, P. F., Mann, K. H. (1982). Effect of antimicrobial substances on the ability of the mysid shrimp Mysis stenolepis to digest cellulose. Mar. Ecol. Prog. Ser. 7 : 309-313

Warner, G. F. (1977). The biology of crabs. Elek, London

Wilson, K. A. (1981). Tidal associated feeding in the man- grove tree crab Aratus pisonii. Am. Zool. 21: 1005 (Abstract)

Wong, E. (1973). Plant phenolics. In: Butler, G. W., Bailey, R. W. (ed.) Chemistry and biochemistry of herbage, Vol. 1 Academic Press, London, p. 265-322

Yingst, J. I. (1976). The utilization of organic matter in shallow marine sediments by an epibenthic deposit feeding Holothurian. J. exp. mar. Biol. Ecol. 23: 55-69

This article was submitted to the editor; it was accepted for printing on August 7,1986 